\section{Nuclear power gets green light from UK government}

The UK government is endorsing the construction of nuclear power plants to help reduce greenhouse-gas emissions. In a white paper released on 10 January, the government promised to streamline licensing procedures, citing global warming and energy security as the driving factors.

The announcement was hailed by supporters of nuclear power as a major step towards an increase in nuclear capacity. "It's a very robust move forward," says David King, the government's former science adviser who is now at the University of Oxford. But environmentalists say that the decision will do little, if anything, to reduce Britain's greenhouse-gas emissions, the vast majority of which come from natural gas and oil use.

Shortly after the announcement, EDF, a French-based firm that is the world's largest operator of nuclear plants, said that it hoped to build up to four reactors on existing nuclear-power sites in Britain.

\section{Health agency recalculates death toll for Iraq conflict}

A survey by the World Health Organization (WHO) has estimated the violence-related death toll in Iraq, between 2003 and 2006, at 104,000-223,000 (Iraq Family Health Survey Study Group N. Engl. J. Med. 358, 484-493; 2008).

The figure is higher than the 47,000 figure given for the same period by the Iraq Body Count, an organization that bases its tally mainly on media reports. And it is much lower than the controversial $426,400-793,700$ deaths estimated by researchers from Johns Hopkins University in Baltimore, Maryland, and the School of Medicine at Al Mustansiriya University in Baghdad, Iraq (see Nature 446, 6-7; 2007).

The latest survey involved a large team of officials from the WHO and Iraq and covered 9,345 households, compared with 1,850 in the Johns Hopkins study. Some critics say that the sample was still too small, but others say that given the difficult conditions in Iraq, and the robustness of the methodology, enough data have been gathered to make the estimated death toll plausible.

Team member Mohamed Ali notes that "nearly 200,000 deaths is not a small number".

\section{Florida funds expansion of Oregon university}

In an unprecedented move, Florida has lured a public university in Oregon to the sunshine state with an offer of $\$ 118$ million to establish a research laboratory there.

Oregon Health \& Science University in Portland last week announced that its Vaccine \& Gene Therapy Institute (VGTI) in Beaverton would expand to Port St Lucie in Florida - where government officials are aggressively funding research facilities to spawn a biotechnology industry (see Nature 442, 729; 2006). It is thought to be the first time that one US state has paid for biomedical research facilities for another state university.

The VGTI, which currently has about 90 staff working for seven principal investigators, expects its facility in Florida to be more than double the size of its Oregon site, which will continue to operate. Florida is providing $\$ 60$ million for operations over a decade, and local governments will fund infrastructure costs.

\title{
Free bags face the axe in China
}

China is clamping down on plastic shopping bags in a bid to clean up the environment and save energy. From 1 June, shopkeepers will no longer be allowed to hand out plastic bags to their customers for free. Failure to charge for the bags could result in a fine. And the manufacture and sale of 'ultrathin' bags - less than 0.025 millimetres thick - will be banned from the same date.

Although this should be good news for the environment, customers feel they are being unfairly burdened. A poll of consumers by the People's Daily,

the official communist newspaper, showed that more than half opposed the ban.

South Africa, Ireland and Bangladesh have already banned or taxed plastic shopping bags and other countries, such as Australia, are considering following suit.

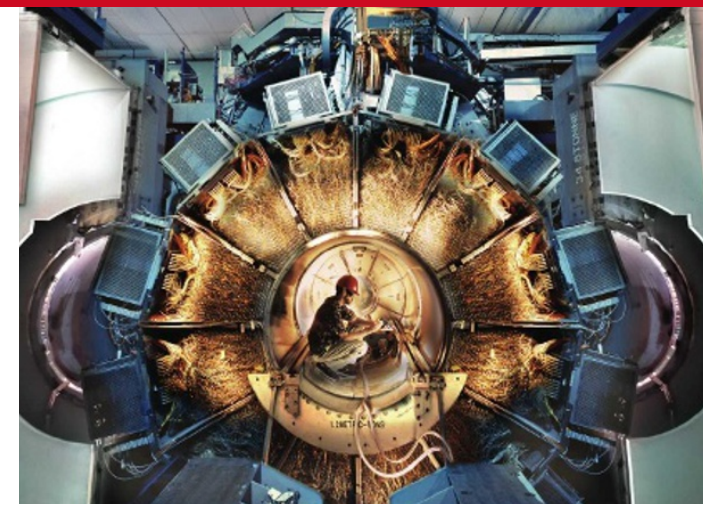

Stanford's B-meson work is coming to an early end.

\section{Budget cuts force early closure of Stanford collider}

In early March, California's Stanford Linear Accelerator Center (SLAC) will shut down a collider that produces $\mathrm{B}$ mesons. The closure means that the lab's commitment to BaBar an international collaboration studying the differences between matter and antimatter - will now end seven months early.

The announcement was made on 7 January by SLAC director Persis Drell after the US Department of Energy gave her its plan to deal with deep budget cuts to high-energy physics. Faced with a choice between keeping SLAC's 'B-factory' open and continuing to run the Tevatron, the high-energy collider at Fermilab in Batavia, Illinois, the department chose the Tevatron, which might detect the Higgs boson before the Large Hadron Collider is turned on at CERN, Europe's particle-physics lab based near Geneva, later this year.

SLAC also plans to lay off 125 of its 1,600 employees in April, on top of an ongoing 100 -person reduction.

\section{Time is running out for paranormal prize}

Challengers for the US\$1-million prize offered by the James Randi Educational Foundation for proving paranormal powers have just over two years left to claim the cash. Randi has announced that the paranormal-activity challenge, in which contestants must demonstrate their powers 'under proper observing conditions', will end on 6 March 2010 - exactly 12 years after he first offered up the prize money.

Randi says that the challenge was intended to tempt high-profile paranormalactivity celebrities to come forward. In 2007, Randi changed the rules of the prize so that applicants were only eligible to enter if they had a media profile and some form of academic endorsement. But as the prize remains unclaimed, and the highest-profile celebrities have not entered, Randi would rather the million dollars were freed to be used elsewhere in his foundation, he says. 